$n$ 次元空間における回転と投影について (I)

On rotations and projections in $n$-dimensional Euclidean space

* 高田 一郎

\title{
Chap.1 序論
}

\section{1 立体の把握}

立体図形（物体）を把握する過程を考察する際、3次元の場合がその唯一の現実的なモデルとなる。そ れは立体を動かし、または観測者が動き、それを見るということに集約される。

例えば我々が未知の物体を把握しようとする際、それを手に取って色々と動かし（回転し）、或いは物 体が大きい場合などはそのまわりを動き回り、眺め、スケッチし、またはシャッターを切るという行動をと ることは誰しあが経験あることであろう。"動かす"ことと"眺める"ことを一般の次元の立体の観察とい う立場で拡張し、それら自身やそれらの相互関係を明らかにすることが本稿の目標である。

ここで注意しておかなければならないことは、図学的見地に立ち物体の正確な把握をするという理由か ら、次の 3 つの条件を満たす物体観察方法の確立を目標とし、これらを常に念頭において考察を加えてい くということである。

$1^{\circ}$ なるべく多くの方向から立体を眺める。

$2 \circ$ 眺めた姿が同じである様な重複を出来る限り少なくする。

$3^{\circ}$ 上を満足しつつ秩序がありかつ実用的である。

これらの表現はいささか標語的であるが、補足しておくと：

1 ○は 1 つの立体を全ての運動によって変換したあらゆる射影像を求めることである。

$2^{\circ}$ は 1 つの立体を異なる運動により変換し射影した 2 つ図形が合同であれば、眺めるという観点か

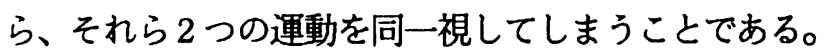

$3^{\circ}$ は運動を系統だてて選択し、眺めた方向や投影図の相互関係 (重複遺漏の有無・程度) が明確にと らえられ、単なる理論に走らず、人間や機械が実際に作図してゆける実用性 一即ち、計算や選択方法が煩 雑になり過ぎないこと一を要求しているものである。

$1^{\circ}$ と $2^{\circ}$ は数学的（理論的）な要請であり、 $3^{\circ}$ は工学的なそれと言えるが、以上のことを単に $n$ 次元空間の一般論として展開するのではなく、3 次元の場合の自然な拡張として捉えていくことにする。

\section{2 運動について (3 次元の場合)}

まず、3 次元的常識から見て、動かすこと即ち運動は少なくとも物体の形を変えない（空間内の）変換 でなくてはならない。形を変えないというのは長さと角を不変にするということに他ならない。（長さ を不変にする変換は角も不変にするので、前者だけ言えば十分である。：詳しく言えば、任意の空間べク トルの長さを不変にし、任意の 2 ベクトル間の角度も不変にするということである。べクトル $\mathbf{v}$ の長さ $|\mathbf{v}|, 2$ ベクトル $\mathbf{v}, \mathbf{w}$ 間の角度 $\theta$ は周知のごとく次のように定義される:

\footnotetext{
“德岛大学棇合科学部
} 


$$
\mathbf{v}=\left(v_{1}, v_{2}, v_{3}\right), \quad \mathbf{w}=\left(w_{1}, w_{2}, w_{3}\right)
$$

に対し、 $\mathbf{v}, \mathbf{w}$ の内積を

$$
\mathbf{v} \cdot \mathbf{w}:=v_{1} w_{1}+v_{2} w_{2}+v_{3} w_{3}
$$

と置くと

$$
\begin{aligned}
|\mathbf{v}|:=\sqrt{\mathbf{v} \cdot \mathbf{v}} & =\sqrt{v_{1}^{2}+v_{2}^{2}+v_{3}^{2}}, \\
\cos \theta: & =\frac{\mathbf{v} \cdot \mathbf{w}}{|\mathbf{v}| \cdot|\mathbf{w}|} .
\end{aligned}
$$

従って、形を変えない空間内の変換は、内積を不変にする変換といってもよい。この様な空間内の変換 の集合のうち、最も一般的な（最も広い）ものは、平行移動と回転, 鏡映で生成された 合同变換群となる。

回転 $\sigma$ には、回転軸 l ( $\sigma$ の不動点全体の集合) があるが ( [3] 第 II 章 § [IV] )、lを原点を通る直線 $l_{0}$ に移す平行移動を $\rho$ とすると、 $\sigma_{0}:=\rho \sigma \rho^{-1}$ は $l_{0}$ を軸とする回転一即ち原点を動かさない回転一とな る。従って任意の回転は、原点を動かさない回転と平行移動によって表される。また、鏡映 $\tau$ には鏡映 面（ の不動点全体の集合）があるが、回転の場合と同様にして、任意の鏡映は原点を不動にする鏡映と 平行移動との積で表される。

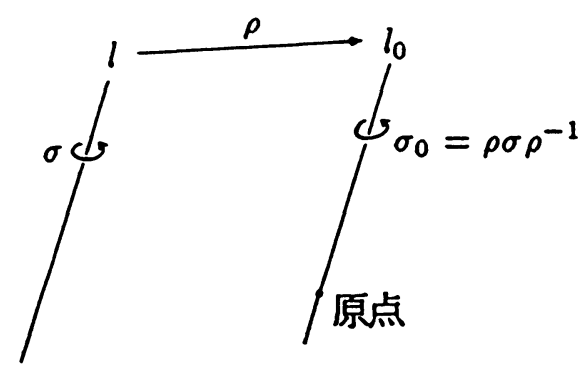

以上まとめると、3 次元空間 $\mathbf{R}^{3}$ 内の形を変えない 変換全体（合同変換群）は、平行移動と 原点を不 動にする 回転及び鏡映で生成されていることがわかる。

原点を不動にする $\mathbf{R}^{3}$ の回転及び鏡映は $\mathbf{R}^{3}$ の一次変換で、その変換行列 $A$ は

$$
{ }^{t} A A=E_{3}
$$

(ここで、 ${ }^{t} A$ は $A$ の転置行列、 $E_{n}$ は $n$ 次の単位行列) を満たす行列一直交行列一であり、逆に、直交 行列を変換行列とする一次変換は、原点を不動にする $\mathbf{R}^{3}$ の回転加鏡映となる。（[2] 第 2 章 $\S 5,6 ，[3]$ 第 II章 §1)

これら全体は、群を成し 直交群 と呼ばれ、

$$
O_{3}:=O_{3}(\mathbf{R}):=\left\{A \in M_{3}(\mathbf{R}) \mid{ }^{t} A A=E_{3}\right\}
$$

と書かれる。但し、 $M_{n}(\mathbf{R})$ は各成分が実数の $n$ 次正方行列全体とする。直交群の元 A に対し $\operatorname{det}^{t} A A=$ $\operatorname{det} E_{3}=1$ と $\operatorname{det}{ }^{t} A=\operatorname{det} A$ より $\operatorname{det} A= \pm 1$ となるので、

$$
O_{3}=\left\{A \in O_{3} \mid \operatorname{det} A=+1\right\} \cup\left\{A \in O_{3} \mid \operatorname{det} A=-1\right\}
$$

と分かれるが、右辺の前半

$$
O_{3}^{+}:=O_{3}^{+}(\mathbf{R}):=\left\{A \in O_{3} \mid \operatorname{det} A=+1\right\}
$$


が、我々が常識的に言う（原点を不動にする）回転全体に一致していて、特にこれを 回転群という。こ れは $\mathrm{SO}_{3}(\mathbf{R}), \mathrm{SO}_{3}, \mathrm{SO}(3)$ などと書かれることもある。一方、

$$
O_{3}^{-}:=\left\{A \in O_{3} \mid \operatorname{det} A=-1\right\}
$$

は 鏡映变換 一原点を通る固定した平面に関する鏡映と回転の積一の全体である。 3 次元の場合、鏡映 変換は運動とは言い難い。というのも鏡映変換により、右手系と左手系が交換されてしまうからである。 例えば分子光学異性体は、互いに鏡映変換で移りあうがその光学的性質が異なるので、3次元常識から言っ て一方を他方に運動させたとは考えない。もちろん一般の次元の場合む、運動から鏡映変換を除くのが適 切であろう。

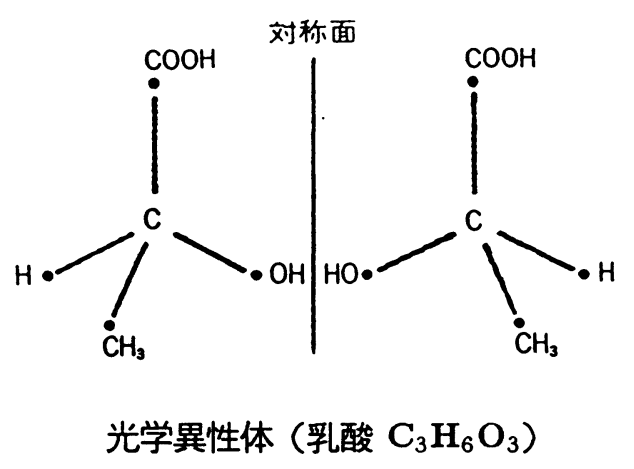

以上まとめると、3 次元空間 $\mathbf{R}^{3}$ の運動は、平行移動と原点を不動にする回転によって生成された变換 ということになる。すちろん、これら全体す群をなし、 $\mathbf{R}^{3}$ の 運動群 と呼ばれる。

因みに、2 次元平面の場合も

$$
O_{2}^{+}(\mathbf{R}):=\left\{A \in O_{2} \mid \operatorname{det} A=+1\right\}=\left\{\left(\begin{array}{cc}
\cos \theta & -\sin \theta \\
\sin \theta & \cos \theta
\end{array}\right) \mid \theta \in \mathbf{R}\right\}
$$

が、原点を不動にする回転全体に一致していることも周知の通りである。

ここで、 $O_{2}:=\left\{\left.A \in M_{2}(\mathbf{R})\right|^{t} A A=E_{2}\right\}$ である。

\section{3 運動について ( $n$ 次元の場合)}

以上のことを踏まえて、任意次元のユークリッド空間における運動・回転について述べることは容易で ある。 $n$ 次元空間 $\mathbf{R}^{n}$ のベクトル

$$
\mathbf{v}=\left(v_{1}, v_{2}, \cdots, v_{n}\right), \quad \mathbf{w}=\left(w_{1}, w_{2}, \cdots, w_{n}\right)
$$

に対し、 $\mathbf{v}, \mathbf{w}$ の内積を

$$
\mathbf{v} \cdot \mathbf{w}:=v_{1} w_{1}+v_{2} w_{2}+\cdots+v_{n} w_{n}
$$

と置けば、 $\mathbf{v}$ の長さ $|\mathbf{v}|, 2$ ベクトル $\mathbf{v}, \mathbf{w}$ 間の角度 $\theta$ は

$$
|\mathbf{v}|:=\sqrt{\mathbf{v} \cdot \mathbf{v}}=\sqrt{v_{1}^{2}+v_{2}^{2}+\cdots+v_{n}^{2}}, \cos \theta:=\frac{\mathbf{v} \cdot \mathbf{w}}{|\mathbf{v}| \cdot|\mathbf{w}|}
$$

で定められる。上で定義された長さと角に対し、それらを不変にし かつ 原点を不動にする $\mathbf{R}^{n}$ の変換全 体は、直交群

$$
O_{n}:=O_{n}(\mathbf{R}):=\left\{\left.A \in M_{n}(\mathbf{R})\right|^{t} A A=E\right\}
$$


であり、

$$
O_{n}=\left\{A \in O_{n} \mid \operatorname{det} A=+1\right\} \cup\left\{A \in O_{n} \mid \operatorname{det} A=-1\right\}
$$

と分けた時、右辺の前半

$$
O_{n}^{+}:=O_{n}^{+}(\mathbf{R}):=\left\{A \in O_{n} \mid \operatorname{det} A=+1\right\}
$$

が、(原点を不動にする) $\mathbf{R}^{n}$ の回転全体であり、回轱群と呼ばれる。 $n$ 次元空間 $\mathbf{R}^{n}$ の運動は、平行移 動と原点を不動にする回転によって生成された変換で、これら全体は $\mathbf{R}^{n}$ の運動群と呼ばれる。

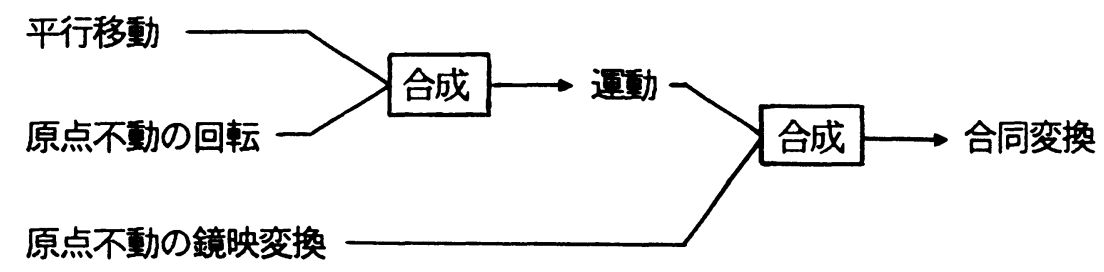

\section{4 投影について}

次に立体を眺めるということについて考察してみる。 3 次元の例 (人間の目や、カメラ等)をモデル に取れば、眺めることは”射影（投影）を行って物体の像を平面に映す”という操作に他ならないことがわ かる。即ち 3 次元図形を、1 つ次元を落とした 2 次元平面へ射影することが "眺める”ことであって、そ の拡張として $\mathbf{R}^{n}$ 内の物体をその空間内のある超平面 $\Pi$ (空間としては $\mathbf{R}^{n-1}$ ) へ射影することが自然に 得られる。

より一般的には、射影する面は超平面でなく、局所的に $\mathbf{R}^{n-1}$ と同相な多様体 とすべきであろう。例 えば、人間の網膜は球面 ( 即ち $S^{2}:=\left\{\left(x_{1}, x_{2}, x_{3}\right) \in \mathbf{R}^{3} \mid x_{1}^{2}+x_{2}^{2}+x_{3}^{2}=1\right\}:$ 局所的には $\mathbf{R}^{2}$ と同相な多 様体 ) の一部と見なせるので、人間の目が物体を眺めるのは、物体の $S^{2}$ への射影ともみられる。しかし 実際、脳においては、その画像が平面への射影として変換されているし、ここでは標準的な図学的見地か ら、射影する曲面を超平面に限っておく。（超) 平面への投影には、正投影 (正射影), 斜投影, 中心投影等 があるが、ここではまず標準的な正投影について考察をしてみる。以下しばらく、単に射影といえば正 射影のことを意味する。

\section{5 運動と投影の相互関係について}

今までは運動と射影とを別々に扱ったが、次に両者の関連性を調べてみることにする。運動は、前述 のように、平行移動と回転のいくつかの合成であったので、それぞれ別個にして考察しよう。

まず平行移動と射影との相互関係は明白である。 即ち、 $\mathbf{R}^{n}$ 内の平行移動は、 $\mathbf{R}^{n}$ 内のベクトル $\mathbf{v} に$

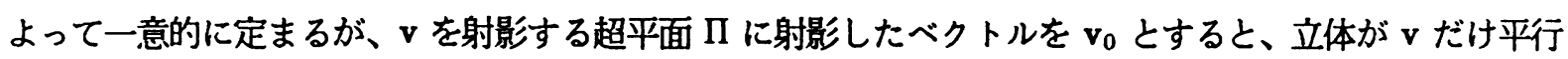
移動すれば、立体の射影は、 $v_{0}$ だけ $\Pi$ 上を平行移動することになる。

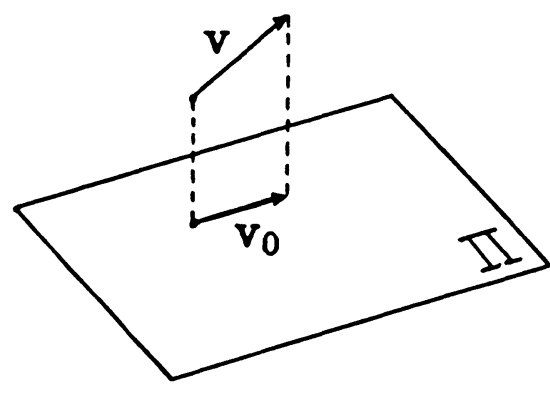


これは、平行移動だけでは結局立体の一側面しか眺められない、ということを意味している。従って、 出来るだけ色々な方向から物体を眺めるという我々の立場からみて、平行移動は考察の対象外として良い であろう。これに対し、回転と射影との相互関係は、上の場合ほど簡単ではない。つまり回転の前後 では、射影された図形は一般には変化している(合同でない)ので、回転は立体を色々な側面から眺める為 に必要かつ本質的な運動であると言えよう。

以下しばらく、回転について考察を加えていくことにする。 $11.2, \S 1.3$ で述べたように、一般の回転 は、原点を不動にする回転と平行移動で生成され、前述のように平行移動は考察の対象外としたことより、 今後考察する回転は原点を不動にする回転（即ち $O_{n}^{+}$の元）だけに限る。

\section{参考文献}

[1] O.T.O'Meara : Introduction to Quadratic Forms, Springer-Verlag, 1973

[2] 齊藤正彦： 線型代数入門 東京大学出版会, 1966

[3] 山内恭彦・杉浦光男 : 連続群論入門 培風館, 1960 


\section{$n$ 次元空間における回転と投影について (II)}

On rotations and projections in $n$-dimensional Euclidean space

* 高田 一郎

\section{Chap.2 回転}

\section{1 回転の図形的（視觉的）表示について}

回転は $O_{n}^{+}$の元、即ち行列で表されるが、このままでは抽象的すぎるので、平行移動の場合のべクトル $\mathbf{v}$ の様な具体的な罒形イメージでその内容を特徵付ける必要がある。 また、なるべく偏りなく色々な方向 から眺めた立体の正射影を求め、もとの立体をより正確に把握する為にす、系統だてて回転をとらえる必 要があろう。

まず初めに、射影する超平面 П は、その法線ベクトルが決まれば一意的に決まるので、その法線べク トルのうち長さが 1 のものを e とする。例えば

$$
\begin{aligned}
& n=2 \text { のときは } \mathrm{e}=(1,0) \text { 即ち } \Pi \text { は } y \text { 軸, } \\
& n=3 \text { のときは } \mathrm{e}=(1,0,0) \text { 即ち } \Pi \text { は } y z \text { 平面, }
\end{aligned}
$$

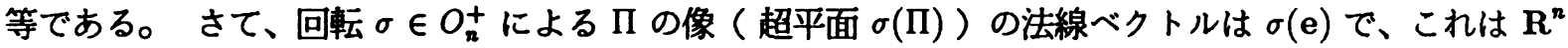
の原点から単位超球面 $S^{n-1}$ へ向かうべクトルであり、 $S^{n-1}$ 上の 1 点を定める。即ち、回転 $\sigma$ に対し、 $S^{n-1}$ 上の 1 点 $P_{\sigma}$ （位置ベクトルが $\left.\sigma(\mathbf{e})\right)$ が一意的に定まる。 以下、この点を Key Ponit にして回転 を系統だてて見ていくことにしよう。
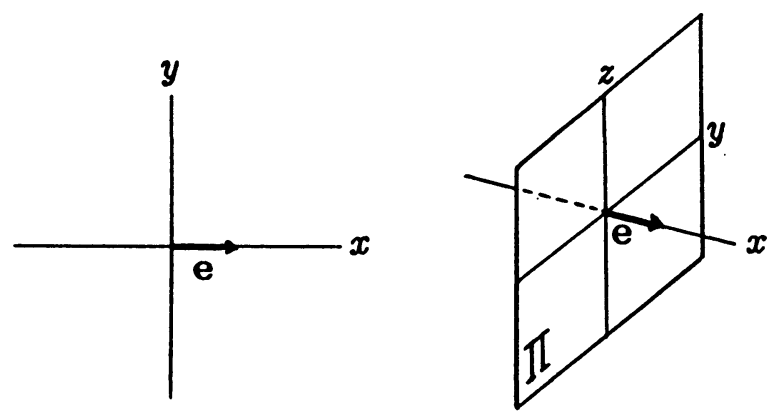

1 つの回転に対して $S^{n-1}$ 上の 1 点が定まったが、逆の対応により $S^{n-1}$ 上の点 1 つに対し、回転が一 意に定まってくれれぱ、 $S^{n-1}$ 上の点と回転全体が 1 対 1 の対応をして大変好都合なのだが、こちらはうま く行かない。つまり $S^{n-1}$ 上の点 $P$ に対し $P=P_{\sigma}$ となる $\sigma \in O_{n}^{+}$が 2 個以上存在するのである。

例えば $n=2$ のとき、円周上の 1 点 $P($ 位置ベクトル $\mathbf{p})$ を固定しても、ベクトル $\mathrm{e}=(1,0)$ を $\mathrm{p}$ に移す回転は、e と $\mathbf{p}$ の成す角を $\theta$ として

$$
\sigma^{[\theta]}:=\left(\begin{array}{cc}
\cos \theta & -\sin \theta \\
\sin \theta & \cos \theta
\end{array}\right), \quad \sigma^{[2 \pi-\theta]}=\left(\begin{array}{cc}
\cos \theta & \sin \theta \\
-\sin \theta & \cos \theta
\end{array}\right)
$$

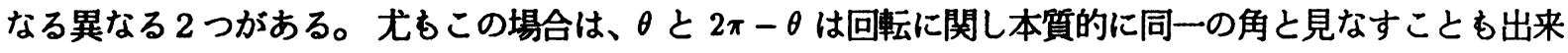

・镐照大学栈合科学部 
るので、円周 $S^{1}$ の点と回転が 1 対 1 の対応をしていると言っても良い。 ところが $n=3$ のときは、球面 上の 1 点 $P($ 位置ベクトル $\mathrm{p})$ を固定しても、ベクトル $\mathrm{e}=(1,0,0)$ を $p$ に移す回転で、回転角のみな らず回転軸さえ異なった本質的に異なるものが無数にある。

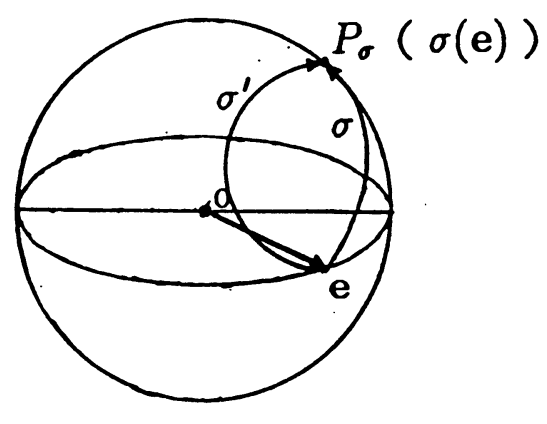

しかし次に示すように、 $\mathbf{R}^{3}$ のベクトル $\mathrm{e}=(1,0,0)$ を球面 $S^{2}$ 上の同一点に移す回転たちは、 $\mathbf{R}^{2}$ の 回転によって結び付けられているのである。 $n>3$ のときす、事情は同じであるので、任意の $n$ に対し $\mathbf{R}^{n}$ のベクトル $\mathbf{e}=(1,0, \cdots, 0)$ を $S^{n-1}$ 上の同一点に移す回転たちが $\mathbf{R}^{n-1}$ の回転によって結び付く ことを示す。

以下、数学的慣例に従い、 $\mathbf{R}^{n}$ の点 $P$ (の座標) と原点を始点とする $P$ の位置ベクトル (の成分) を同一 視し、さらに行列計算の都合等により、それを $\left(x_{1}, \cdots, x_{n}\right)$ と記す場合も $\left(\begin{array}{c}x_{1} \\ : \\ x_{n}\end{array}\right)$ と記す場合あある。

Lemma $2.1 \sigma, \sigma^{\prime} \in O_{n}^{+}$が、

$$
\sigma\left(\begin{array}{c}
1 \\
0 \\
: \\
0
\end{array}\right)=\sigma^{\prime}\left(\begin{array}{c}
1 \\
0 \\
: \\
0
\end{array}\right)
$$

なる関係を満たせば、

$$
\sigma^{\prime}=\sigma\left(\begin{array}{cc}
1 & 0 \\
0 & \tau
\end{array}\right), \quad \tau \in O_{n-1}^{+}
$$

が成り立つ。

（証明）仮定より、

$$
\left(\begin{array}{c}
1 \\
0 \\
: \\
0
\end{array}\right)=\sigma^{-1} \sigma^{\prime}\left(\begin{array}{c}
1 \\
0 \\
: \\
0
\end{array}\right)
$$

ここで

$$
\rho:=\sigma^{-1} \sigma^{\prime} \in O_{n}^{+}
$$


とおくと、(2.1)式より

$$
\rho=\left(\begin{array}{c|ccc}
1 & a_{1} & \cdots & a_{n} \\
\hline 0 & & & \\
: & & \tau & \\
0 & &
\end{array}\right)
$$

但し、 $a_{1}, \cdots, a_{n} \in \mathbf{R}, \tau \in M_{\mathbf{n}}(\mathbf{R})$ となるが、 $\rho \in O_{n}^{+}$より

$$
\left(\begin{array}{c|c}
1+a_{1}^{2}+\cdots+a_{n}^{2} & * \\
\hline * & \tau^{t} \tau
\end{array}\right)=\rho^{t} \rho=E_{\mathrm{n}}={ }^{t} \rho \rho=\left(\begin{array}{c|c}
1 & * \\
\hline * & { }^{t} \tau \tau+\left(\begin{array}{c}
a_{1} \\
: \\
a_{n}
\end{array}\right)\left(\begin{array}{lll}
a_{1} & \cdots & a_{n}
\end{array}\right)
\end{array}\right)
$$

従って

$$
\begin{gathered}
a_{1}=\cdots=a_{n}=0, \\
\tau^{t} \tau={ }^{t} \tau \tau=E_{n-1} .
\end{gathered}
$$

即ち

$$
\tau \in O_{n-1}^{+}
$$

を得る。

q. e. d.

上の結果について 3 次元の場合を例に取って簡単に触れてみる。 $\left(\begin{array}{ll}1 & 0 \\ 0 & \tau\end{array}\right)$ は $\mathbf{e}=(1,0,0)$ を法線 ベクトルとする平面 П の上での回転であるから、Lemma 2.1 より e を球面 $S^{2}$ 上の同一点に移す回転 $\sigma$ と $\sigma^{\prime}$ は平面 П 上での回転倍の差異しか無く、 $\sigma$ と $\sigma^{\prime}$ による運動後の射影像たちは $\Pi$ 上で合同である。 従って、П を投影面とする（一般に投影面は任意に取って固定しておけば良いので んししておいても一般 性を失わない）正投影を考察する限りにおいては、 $\sigma$ と $\sigma^{\prime}$ は同一物として良い。よって次のような関係 が得られる :

球面 $S^{2}$ 上の一点 $\longleftrightarrow$ 合同の投影像を持つ $\mathbf{R}^{3}$ の回転

あちろん一般の次元についても同様の関係が得られる。

Lemma 2.1 を数学的に約言すれば、3 次元の場合、空間の回転全体と球面 $S^{2}$ 上の点は 1 対 1 に対応 しなかったが、3 次元空間の回転全体 $O_{3}^{+}$を 2 次元平面の回転倍の差異だけがあるすのを一まとめにした 同值類集合 $O_{3}^{+} / O_{2}^{+}$と $S^{2}$ が 1 対 1 に対応することを言っている。一般に $O_{n}^{+}$と $S^{n-1}$ は 1 対 1 に対応し ないが、 $O_{n}^{+}$を $O_{n-1}^{+}$で割った同值類集合（商集合）が 1 対 1 に対応している。即ち

$$
O_{n}^{+} / O_{n-1}^{+} \simeq S^{n-1}
$$

次に、Lemma 2.1 を用いて 回転を系統だてて捉えてみることにする。 


\section{2 回転の系統的な表示について (2 次元，3次元の場合)}

まず、2次元平面の場合の回転が基本的なモデルとなる。前にも述べたが、2次元の場合は $\sigma \in O_{2}^{+} に$ 対し、

$$
\sigma=\sigma^{[\theta]}:=\left(\begin{array}{cc}
\cos \theta & -\sin \theta \\
\sin \theta & \cos \theta
\end{array}\right)
$$

となる $\theta \in \mathbf{R}$ が取れる。特に、 $T=\{\theta \in \mathbf{R} \mid 0 \leq \theta<2 \pi\}$ とすれば、 $O_{2}^{+}$と $T$ は 1 対 1 に対応する。 ( i.e. $O_{2}^{+} \simeq \mathbf{R} / 2 \pi \mathbf{Z}$ ) つまり、2 次元の回転は、1つのパラメータ $\theta$ で生成されている。

3 次元の場合、

$$
\begin{aligned}
& R_{1}:=\left\{\left(\begin{array}{ccc}
1 & 0 & 0 \\
0 & \cos \theta & -\sin \theta \\
0 & \sin \theta & \cos \theta
\end{array}\right) \mid \theta \in \mathbf{R}\right\}: x \text { 軸回りの }(y z \text { 平面上の }) \text { 回転全体， } \\
& R_{2}:=\left\{\left(\begin{array}{ccc}
\cos \theta & -\sin \theta & 0 \\
\sin \theta & \cos \theta & 0 \\
0 & 0 & 1
\end{array}\right) \mid \theta \in \mathbf{R}\right\}: z \text { 軸回りの回転全体， } \\
& R_{3}:=\left\{\left(\begin{array}{ccc}
\cos \theta & 0 & -\sin \theta \\
0 & 1 & 0 \\
\sin \theta & 0 & \cos \theta
\end{array}\right) \mid \theta \in \mathbf{R}\right\}: y \text { 軸回りの回転全体 }
\end{aligned}
$$

と置くとこれらはそれぞれ $O_{3}^{+}$の部分群を成している。このとき次の命題が成り立つ。

$\underline{\text { Proposition 2.2 }}$ 任意の $\sigma \in O_{3}^{+}$は、

$$
\sigma=\sigma_{1} \sigma_{2} \sigma_{3}
$$

と分解される。但し、 $\sigma_{i} \in R_{i} ， i=1,2,3$.

（証明） $\sigma \in O_{3}^{+}$に対して、 $\mathbf{p}:=\sigma^{-1}\left(\begin{array}{l}1 \\ 0 \\ 0\end{array}\right)$ とおくと、 $\mathbf{p}$ は球面上の 1 点(の位置ベクトル)を定め る。 また $\sigma_{2} \in R_{2}, \sigma_{3} \in R_{3}$ が存在して、

$$
\sigma_{2} \sigma_{3}(\mathbf{p})=\left(\begin{array}{l}
1 \\
0 \\
0
\end{array}\right)
$$

となる。故に

$$
\sigma^{-1}\left(\begin{array}{l}
1 \\
0 \\
0
\end{array}\right)=\sigma_{3}^{-1} \sigma_{2}^{-1}\left(\begin{array}{l}
1 \\
0 \\
0
\end{array}\right)
$$

従って、Lemma 2.1 より

$$
\sigma^{-1}=\sigma_{3}^{-1} \sigma_{2}^{-1}\left(\begin{array}{cc}
1 & 0 \\
0 & \tau
\end{array}\right), \tau \in O_{2}^{+}
$$

即与

$$
\sigma=\left(\begin{array}{cc}
1 & 0 \\
0 & \tau^{-1}
\end{array}\right) \sigma_{2} \sigma_{3}
$$


を得る。よって

$$
\sigma_{1}:=\left(\begin{array}{cc}
1 & 0 \\
0 & \tau^{-1}
\end{array}\right) \in R_{1}
$$

と置けば、命題を得る。

q. e. d.

この命題より、

$\sigma_{1}^{\left[\theta_{1}\right]}:=\left(\begin{array}{ccc}1 & 0 & 0 \\ 0 & \cos \theta_{1} & -\sin \theta_{1} \\ 0 & \sin \theta_{1} & \cos \theta_{1}\end{array}\right), \sigma_{2}^{\left[\theta_{2}\right]}:=\left(\begin{array}{ccc}\cos \theta_{2} & 0 & -\sin \theta_{2} \\ 0 & 1 & 0 \\ \sin \theta_{2} & 0 & \cos \theta_{2}\end{array}\right), \sigma_{3}^{\left[\theta_{3}\right]}:=\left(\begin{array}{ccc}\cos \theta_{3} & -\sin \theta_{3} & 0 \\ \sin \theta_{3} & \cos \theta_{3} & 0 \\ 0 & 0 & 1\end{array}\right)$

之置いて、 $\theta_{1}, \theta_{2}, \theta_{3}$ を 0 と $2 \pi$ の間を動かせば、 $\sigma_{1}^{\left[\theta_{1}\right]} \cdot \sigma_{2}^{\left[\theta_{2}\right]} \cdot \sigma_{3}^{\left[\theta_{3}\right]}$ により、全ての 3 次元回転が得られる。 しかし、1 つの回転を実数の組 $\left(\theta_{1}, \theta_{2}, \theta_{3}\right)$ で表す方法は一意的ではない。 また、Proposition 2.2 と同 様の証明により、例えば、任意の $\sigma \in O_{3}^{+}$は、

$$
\sigma=\sigma_{1} \sigma_{3} \sigma_{2} \quad\left(\sigma_{i} \in R_{i}, i=1,2,3\right)
$$

とも分解されることもかかる。るちろん、これら $\theta_{1}, \theta_{2}, \theta_{3}$ は一般には上の命題のものと (回転角が) 異 なるであろう。 無論より一般に、 $\sigma \in O_{3}^{+}$は、

$$
\sigma=\sigma_{i_{1}} \sigma_{i_{2}} \sigma_{i_{3}}, \quad\left\{i_{1}, i_{2}, i_{3}\right\}=\{1,2,3\} \quad\left(\sigma_{i} \in R_{i}, i=1,2,3\right)
$$

と分解される。

また、 $\sigma_{1}$ は $\mathbf{e}=(1,0,0)$ を法線べクトルとする平面 П（前述のようにこれを投影面として良い）の 上での回転であり、投影後の図形の回転を引き起こすだけであるので物体の観察と言う我々の立場からは無 視して良い。従って、 $\sigma_{2}$ と $\sigma_{3}$ の 2 種類の回転によって欲しい回転が全て得られることになる。換言す れば、3 次元の回転は上記 $\sigma_{2}^{\left[\theta_{2}\right]}, \sigma_{3}^{\left[\theta_{3}\right]}$ の 2 つのパラメータ $\theta_{2}, \theta_{3}$ により生成されていることになる。 同様のことが一般の次元の回転についても成立する。以下このことについて考察していく。 
$n$ 次元空間における回転と投影について (III)

On rotations and projections in $n$-dimensional Euclidean space

* 高田 一郎

\section{3 回転の系統的な表示について $(n$ 次元の場合)}

まず、 $n$ 次元空間 $\mathbf{R}^{n}$ の正規直交基底を

$$
\mathbf{e}_{1}:=(1,0, \cdot ., 0), \mathbf{e}_{2}:=(0,1,0, \cdots, 0), \cdots, \mathbf{e}_{n}:=(0, \cdots, 0,1)
$$

とし、

$$
R_{i}:=\left\{\left(\begin{array}{cccccccc}
\cos \theta & 0 & . . & 0 & -\sin \theta & 0 & & 0 \\
0 & 1 & \ddots & : & 0 & & & \\
: & \ddots & \ddots & 0 & : & : & & \\
0 & . . & 0 & 1 & 0 & & & : \\
\sin \theta & 0 & . . & 0 & \cos \theta & 0 & & \\
0 & & . . & & 0 & 1 & \ddots & \\
: & & & & & \ddots & \ddots & 0 \\
0 & & & . . & & & 0 & 1
\end{array}\right) \mid \theta \in \mathbf{R}\right\}=\left\{\sigma \in O_{n}^{+} \mid \sigma \mathbf{e}_{j}=\mathbf{e}_{j}, j \neq 1, i\right\}
$$

すなわち $\mathrm{e}_{1}, \mathrm{e}_{i}$ 以外の全ての $\mathrm{e}_{j}$ を不変にする $\mathrm{R}^{n}$ の回転で、本質的には $\mathrm{e}_{1}, \mathrm{e}_{i}$ で張られた 2 次元平面上 の角 $\theta$ の回転とおく。

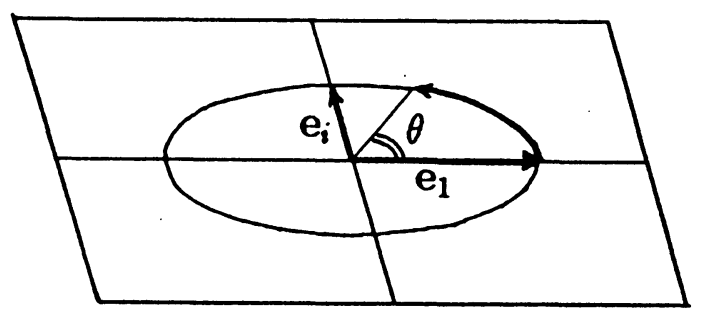

Lemma 2.3 $\mathbf{p}$ を $\mathbf{R}^{n}$ の単位 (超) 球面上の 1 点 (i.e. $\mathbf{p} \in S^{n-1}$ ) とするとき、 適当な $\sigma_{i} \in R_{i}(i=2,3, \cdot \cdot, n)$ があって、

$$
\mathbf{p}=\sigma_{2} \sigma_{3} \cdots \sigma_{n}\left(\mathbf{e}_{1}\right)
$$

となる。

\footnotetext{
德島大学棇合科学部
} 
（証明） $n$ に関する㷌納法による。 $n=2$ のとき、 $\mathrm{p}$ と $\mathrm{e}_{1}$ の成す角を $\theta$ として、 $\sigma_{2}=\left(\begin{array}{cc}\cos \theta & -\sin \theta \\ \sin \theta & \cos \theta\end{array}\right)$ ととれば

$$
\mathbf{p}=\sigma_{2}\left(\mathbf{e}_{1}\right)
$$

を得る。 $n>2$ のとき、 $\mathrm{p}=:\left(p_{1}, \cdots, p_{n-1}, p_{n}\right)$ として

$$
\tilde{\mathbf{p}}:=\left(p_{1}, \cdots, p_{n-1}, 0\right), k:=|\tilde{\mathbf{p}}|
$$

とおくと、 $\left|\frac{1}{k} \tilde{\mathbf{p}}\right|=1$ より、 $\frac{1}{k} \tilde{\mathbf{p}}$ は、 $\mathbf{e}_{1}, \cdots, \mathbf{e}_{n-1}$ たちで張られる $n-1$ 次元空間の単位球面上の 1 点であ る。故に、㷌納法の仮定加ら

$$
\frac{1}{k} \tilde{\mathbf{p}}=\sigma_{2} \cdots \sigma_{n-1}\left(\mathbf{e}_{1}\right), \sigma_{i} \in R_{i}
$$

とできる。従って、

$$
\mathbf{p}=\left(p_{1}, \cdots, p_{n-1}, 0\right)+\left(0, \cdots, 0, p_{n}\right)=\tilde{\mathbf{p}}+p_{n} \mathbf{e}_{n}=\sigma_{2} \cdots \sigma_{n-1}\left(k \mathbf{e}_{1}\right)+p_{n} \mathbf{e}_{n}
$$

ところが、 $\mathbf{e}_{n}$ は $\sigma_{2}, \cdots, \sigma_{n-1}$ の作用では不変より、

$$
\mathbf{p}=\sigma_{2} \cdots \sigma_{n-1}\left(k \mathbf{e}_{1}+p_{n} \mathbf{e}_{n}\right) .
$$

ここで $k^{2}+p_{n}^{2}=|\mathrm{p}|^{2}=1$ であるから、 $k \mathrm{e}_{1}+p_{n} \mathrm{e}_{n}$ は $\mathrm{e}_{1}$ と $\mathrm{e}_{n}$ で張られる 2 次元空間内の単位球面 (円周) 上の点となる。従って $n=2$ の場合の結論より、適当な $\sigma_{n} \in R_{n}$ が存在して

$$
k \mathbf{e}_{1}+p_{n} \mathbf{e}_{n}=\sigma_{n}\left(\mathbf{e}_{1}\right) \text {. }
$$

これと (2.2) 式と合わせて結論を得る。

q. e. d.

さてここで

$$
R_{1}:=\left\{\sigma \in O_{n}^{+} \mid \sigma \mathbf{e}_{1}=\mathbf{e}_{1}\right\}=\left\{\left(\begin{array}{cc}
1 & 0 \\
0 & \tau
\end{array}\right) \mid \tau \in O_{n-1}^{+}\right\}
$$

とおく。これは、 $\mathbf{e}_{1}$ を不変にする $\mathbf{R}^{n}$ の回転一即ち $\mathbf{e}_{1}$ を法線ベクトルとする超平面（投影面）内の回 転一全体の集合である。このとき次の補題が成り立つ。

Lemma 2.4 $\mathbf{R}^{n}$ の全ての回転 $\sigma \in O_{n}^{+}$に対し、適当な $\sigma_{i} \in R_{i}(i=1,2, \cdot \cdot, n)$ が存在し

$$
\sigma=\sigma_{2} \sigma_{3} \cdots \sigma_{n} \sigma_{1}
$$

となる。

（証明） $\sigma\left(\mathbf{e}_{1}\right)$ は $\mathbf{R}^{n}$ の単位球面上の点より Lemma 2.3 から

$$
\sigma\left(\mathbf{e}_{1}\right)=\sigma_{2} \sigma_{3} \cdots \sigma_{n}\left(\mathbf{e}_{1}\right), \sigma_{i} \in R_{i}(i=2,3, \therefore, n) .
$$

故に Lemma 2.1 より

$$
\sigma=\sigma_{2} \sigma_{3} \cdots \sigma_{n}\left(\begin{array}{cc}
1 & 0 \\
0 & \tau
\end{array}\right), \tau \in O_{n-1}^{+}
$$

を得るので、 $\sigma_{1}:=\left(\begin{array}{cc}1 & 0 \\ 0 & \tau\end{array}\right) \in R_{1}$ とおけば良い。 
q. e. d.

Proposition 2.5 $\mathbf{R}^{n}$ の全ての回転 $\sigma \in O_{n}^{+}$に対し、適当な $\sigma_{i} \in R_{i}(i=1,2, \cdot, n)$ が存在して

$$
\sigma=\sigma_{1} \sigma_{2} \sigma_{3} \cdots \sigma_{n}
$$

となる。

（証明） $\mathbf{R}^{n}$ の正規直交基底の一部である $\mathbf{e}_{2}, \cdots, \mathbf{e}_{n}$ の番号だけを逆順に入れ換えて Lemma 2.4 を $\sigma^{-1} \in O_{n}^{+}$に対して適用すると、

$$
\sigma^{-1}=\tilde{\sigma_{n}} \cdots \tilde{\sigma_{3}} \tilde{\sigma_{2}} \tilde{\sigma_{1}}, \quad \tilde{\sigma_{i}} \in R_{i}(i=1,2, \cdot \cdot, n),
$$

即ち、

$$
\sigma={\tilde{\sigma_{1}}}^{-1}{\tilde{\sigma_{2}}}^{-1} \cdots{\tilde{\sigma_{n}}}^{-1}
$$

を得る。ここで、 $\sigma_{i}:=\tilde{\sigma}_{i}^{-1} \in R_{i}(i=1,2, \cdot \cdot n)$ とおけば命題を得る。

q. e. d.

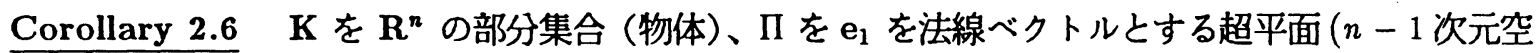
間) とする。このとき、 $\sigma \in O_{n}^{+}$を $\mathbf{R}^{n}$ の任意の回転に対し、適当な $\sigma_{i} \in R_{i}(i=2,3, \cdot \cdot n)$ が存在して

$$
\sigma(\mathbf{K}) \text { と } \sigma_{2} \sigma_{3} \cdots \sigma_{n}(\mathbf{K})
$$

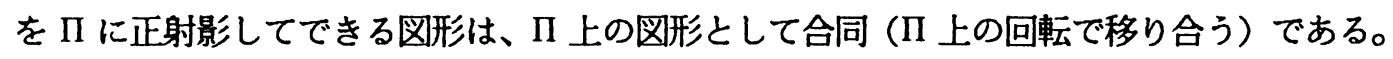

ここで、 $\mathbf{R}^{n}$ の点(の位置べクトル) $\mathbf{p}=\left(p_{1}, p_{2}, \cdots, p_{n}\right)$ の П への正射影とは、 $\Pi$ 上の点 $\left(0, p_{2}, \cdots, p_{n}\right)$ のことである。

（証明） $\sigma_{1} \in R_{1}$ は $\mathrm{e}_{1}$ を法線ベクトルとする超平面上の回転であるので、Proposition 2.5 より直ち に系を得る。

q. e. d.

かくして、 $n$ 次元空間の物体を正射影して "眺める”という我々の立場においては、物体の運動として $\sigma_{2}, \sigma_{3}, \cdots, \sigma_{n}$ なる $n-1$ 個の "固定された” 2 次元平面上の回転だけを取れば十分であることがわかった。

実直交行列の標準形 ([2] 第 5 章 系 [6.2])、或いはより一般に Cartan-Dミeudonnè の定理 ([1] Chap.IV Theorem 43:3) から、 $n$ 次元空間 $\mathbf{R}^{n}$ の任意の回転は $\frac{n}{2}$ 個以下の "適: 沈” 2 次元平面上の回転たちの積 で表されることがわかるので、単に回転だけを理論的に捉えるだけであればこれで十分であるとも言えよ う。しかしこれは所謂存在定理であり、構成要素となる回転を与える 2 次元平面を具体的に求めることは 一般に困難であり、都合が悪いことにこれらの 2 次元平面は、初めに与えられる回転に依存して変化して

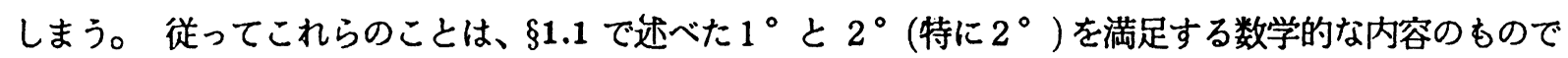
あるが、残念ながら $3^{\circ}$ が満たされておらず、図学的な立場から実用的であるとは言えない。よって我々 は、 $2^{\circ}$ を少々儀牲にしてであ（§2.2 参照） $3^{\circ}$ を取り、Corollary 2.6 のような形式を得るのである。 
参考文献

[1] O.T.O'Meara : Introduction to Quadratic Forms, Springer-Verlag, 1973

[2] 齊藤正彦： 線型代数入門 東京大学出版会, 1966

[3] 山内恭彦・杉浦光男 : 連続群論入門 培風館, 1960 